\title{
The Eighteenth Century or Fin-de-Siècle Beginnings
}

\author{
Diane Fourny
}

W

HILE WORKING ON THIS ESSAY, I was interrupted one morning by a National Public Radio broadcast reporting what I can only call a fin-de-siècle "happening." According to the broadcaster a group of concerned French citizens was mounting a campaign to purge France's national anthem of its bellicose lyrics. This furor over the Marseillaise had arisen over its delivery at the opening ceremonies of the Olympic Winter Games in Albertville when ten-year-old Séverine Dupelloux, unaccompanied, sang the national anthem before an audience of hundreds present and millions worldwide via satellite television. As her small, uplifted voice poignantly resonated throughout the arena, TV viewers everywhere could follow the anthem's lyrics being simultaneously translated by subtitles flashed across their screens. Somehow, there arose a certain incongruity between the child's innocent voice and "furrows of blood" in the minds of some viewers, suggesting scandal, worse yet-a brutal, erotically charged image of lost innocence filling an already excited night air of competitive sports. Something had to be done. Yet, no sooner had a campaign to change the anthem's lyrics formed than a countergroup, calling itself the Committee for the Defense of the Marseillaise, demanded a "hands off" policy, accusing those reform-minded individuals of totalitarian-type leanings, suggesting that only a regime like the former Soviet Union would dare to "rewrite" history. ${ }^{1}$

Criticizing the Marseillaise's violent overtures to war and the spilling of enemy blood is hardly new. ${ }^{2}$ Nor should it come as any surprise that during this our most "postmodern" hour, political activists on the Left (Danielle Mitterrand being the most striking sympathizer of the reform campaign) should deny their historical debt to the revolutionary rhetoric of 1789. Given a context of fin-de-siècle as such, the Marseillaise "happening" should be read as a repetition of that simultaneous emergence and reversal of political extremes at both ends of the ideological spectrum so frequently expressed under fin-de-siècle Europe a hundred years ago-let it not be forgotten-at a time when the first modern Greek Olympic Games were being initiated internationally in 1894. The irony, or more aptly, discomfort here-that the Marseillaise should create a 


\section{L'ESPRIT CRÉATEUR}

scandal at these first Olympic Games since the fall of the Berlin Walllay in the fact that as the very notion of political animosity had all but been eradicated (so say the proponents of a "New World Order"), up popped the ugly head of political contention once again in the form of censorship by the Left on the one hand and conservative chauvinism on the other. Furthermore, what to make of the lackluster medal showing by the Americans and the oxymoronic presence of the former Soviet Union's "Unified Team"? And should the hoarding of the gold, silver, and bronze by "Old Europe" become a new source of speculation (the Germans and Austrians in particular, though France also collected more medals than in recent past Olympics)? Had the spirit of 1992 Games been contaminated with that of the politically charged Games of 1894-1904? ${ }^{3}$

France's collective discomfiture with Séverine Dupelloux's rendition of the Marseillaise - which should also be read as the very eroticization of that voice-points to a deep and often times, mystified filiation to finde-siècle aesthetics and ideology of the French Revolution. In this essay, I will argue that the spirit of fin-de-siècle begins with the French Revolution as principle of a regenerative force. In many respects, the fin-desiècle reiterates a desire to rejoin sacred time, the time of violent social upheavals and of new foundations. At the same time it refuses to fulfill such a desire, out of fear or perhaps fatigue, that new foundations remain merely repetitions of the same. If thinkers of modernity are correct in seeing this period as pivotal-the French Revolution validating a historical consciousness of a new age defined as a present open onto the future and which has to create its normativity out of itself-then fin-desiècle, being the symptomatic articulation of modernity, must also find its origins in this period. ${ }^{4}$ The French Revolution did not so much "invent" the fin-de-siècle as it incarnated it prior to its inception, giving us three of its major expressions: the desire to destabilize time or to "erase" history as such; the condemnation of modern society as degenerate, corrupt, and exhausted, along with the simultaneous dream (of messianic and/or utopian dimensions) of society's regeneration; and the disruption of certain philosophical traditions by new "systems" that undermine ontological suppositions.

The Left's odd preoccupation with the eroticization of lost innocence (Séverine Depelloux) can be traced to the fin-de-siècle of 1789. I am referring here to any one of J.-L. David's martyr paintings, particularly to his unfinished depiction of Joseph Bara (1797), the boy-victim of the bloody counter-Revolution. ${ }^{5}$ Whereas the Revolutionary gaze fully and 
FOURNY

publicly embraces the eroticization as a regenerative tool to forge new beginnings, later fin-de-siècle representations repress it in a neurotic play of recuperation and loss: its aesthetic gaze seems only to recuperate it in a nostalgic bow to allegory. ${ }^{6}$ David's depiction of Bara transmits the very pregnancy of violence, just as his Marat drew the spectator into the paradoxical life force of death as Baudelaire reminds us:

Le drame est là, vivant dans toute sa lamentable horreur, et par un tour de force étrange qui fait de cette peinture le chef-d'œuvre de David et une des grandes curiosités de l'art moderne, elle n'a rien de trivial ni d'ignoble... la Mort vient du baiser de ses lèvres amoureuses, et il repose dans le calme de sa métamorphose. II y a dans cette oeuvre quelque chose de tendre et de poignant à la fois, dans l'air froid de cette chambre, sur ces murs froids, autour de cette froide et funèbre baignoire, une âme voltige. ${ }^{7}$

The Marat assassiné transforms death as the cessation of life into a different sort of "end," that transforms itself into a "means" toward the continual struggle for revolutionary action and ideals. David's "piéta jacobine" ${ }^{8}$ is pregnant with a retaliatory violence its spectators are invited to seize and expand upon in an identical and eternal gesture of destruction and regeneration. The wooden box serving as Marat's écritoire serves here as the martyr's tombstone with its stark and obvious commemorative inscription "A Marat, David." And yet, unlike normal headstones, no date has been inscribed between the deadman's name and the living, since in the logics of martyrology death serves precisely the function of shattering the historical time in order to enter the open time of sacrifice. History is plunged into the eternity of the present and the unburied martyr ensures by the testimony of his still warm body that history lives on and in the present moment. In the Bara painting, the martyred boy is also that living testimony to the citizen's call to sacrifice, to see destruction as principle of regeneration. Through death, Bara's virtue lives on. Body delivered from history, the boy's uplifted head draws a line to the immediate future of the spectator's outrage. Everything in the unfinished painting points to its timelessness: the irrelevancy of the boy's nudity, the upturned face of the fallen body, Bara's sexlessness, the absent (abdominal) wound, the hand still clutching the trocard, and the uncertainty that the boy has in fact died. Finally, it is Bara's erotic poise and facial expression delivered before the spectator that transforms this scene of innocence violated into yet another invitation to embrace a regenerative violence that desires to avenge the boy-victim. David's painting washes the corruption of the old with the corruption of

VoL. XXXII, No. 4 


\section{L'ESPRIT CRÉATEUR}

the new: the ambivalent combination of blood and nudity, death as regeneration and youthful violence as destruction.

A commonly held view of the fin-de-siècle spirit is embodied in the fatigue and malaise of the decadent: a subject seeking to invigorate his exhausted life by making a fashionable, transgressive or nostalgic gesture toward that which escapes the dull normalcy of everyday life. Yet, no sooner has the gesture been made then it reveals itself inadequate to transform life, exposes its outdated and exhausted shell. The exhaustion of decadent culture is aptly summarized by the phrase Barbey d'Aurevilly used for his letter seal, "Too Late," or for that matter, our own fin-desiècle mantra, the "toujours déjà." Yet to read fin-de-siècle decadence as merely a static withdrawal from a present whose future has already been written is to see only half the picture. Alongside its inertia one finds its counterpart in the apocalyptic vision: no commitment to the present, nor to the values and products of modern society, fin-de-siècle spirit sees fit to entertain the notion of destruction and anarchism. Whether disgusted or mistrustful of positivism and technological innovation, or embittered by the egotistical and conformist materialism of bourgeois culture, or scandalized, like Mallarmé, by the pure contingency of the real (and symbolic, for that matter), or repulsed by the new religion of secular republicanism, elements on both the Left and Right of the intellectual and political spectra abjure an uncompromising destruction of society. And by so doing, certain hope to usher in the future races of the disinherited masses, while others desire a quasi-mystical return to some deeper order of a lost Golden Age peopled by a small elite of energized souls. Escape through nostalgia or utopism finds its counterpart in the contemplation of a very real violence directed toward social values and institutions. In this manner, E. Weber describes fin-de-siècle debate in the throes of dynamic oppositions: decadence and regeneration, production and destruction, ruins and new inventions, economic and moral depression and new hopes and inspirations. Political instability and public scandal seem to coincide, even complement what is perceived as an inordinate increase in crime, pathological illness, and venereal disease. Fin-de-siècle France marked a "period of manifold signs and prodigies of things to come," however, what was to come might prove to be nothing more than "a world and an age coming to a close." 9

Whether speaking of the Symbolists' suspicion of reality because it masked the true expression of the idea, the distaste and ridicule of a Huysmans or a Villiers de L'Isle-Adam before science and the "esprit moderne," or the verbal terrorism of Ubu, the fin-de-siècle's flight from 
the present must also be read as a flight from historical determinism inasmuch as it meant the negation of life, of force, energy, and "élan." Our own fin-de-siècle reveals a similar discomfort with history when a Washington bureaucrat makes headlines by assessing the current fin-de-siècle as the triumph over history, or to use his words, the triumphant "end of history." Fukuyama's thesis eerily echoes what C. E. Schorske has identified as symptomatic of fin-de-siècle Europe a century ago, as the desire for the "death of history" characterized by a "collective oedipal revolt" of the son against the authority of the paternal culture that was their inheritance. ${ }^{10}$ Fritz Stern also identifies this characteristic "refusal of history" in his study of fin-de-siècle Germany as a "struggle against modernity," during which time dispossessed intellectuals speak prophecies of impending doom of the present state and its utopian redemption through a mystical fusion of art and politics. ${ }^{11}$

It is perhaps indicative of the times that Bergson's Essai sur les données immédiates de la conscience (1889) and Freud's Interpretation of Dreams (1900) return us to the notion of a "vie intérieure," an unconscious nod perhaps to another writer of "la voix intérieure" whose works would indelibly mark an entire fin-de-siècle generation of philosophers and novelists of revolutionary France, J.-J. Rousseau. Or, as Weber again suggests, in the "absence of an ultimate objective reality, the subjective experience becomes the important thing" (p. 143). The fin-desiècle portrays itself as initiating a new exploration of the inner depths of the imagination, sensations, and intuitive thought, and its artistic productions, the translation of these new discoveries and experiences into a visual, aural, and symbolic language that could "express and suggest feelings . . . more significant than the objective surface realities. . ." (p. 147). If the philosophy of Schopenhauer enjoys such enormous success during this time, it is not only due to his pessimistic rejection of modernity but also equally to his exploration of the notion of will: a primary and universal force underlying reality that carries the subject beyond or outside of history. Caricatural in their exaltation of volonté, Barrès' autobiographical novels under the title of Le Culte du Moi (1888-1891) exemplify the fin-de-siècle nurturing of this inner experience. First, one must protect oneself at all cost from the encroachment of others, from the "barbarians." Second, in solitude the self must delve into the deepest recesses of its thought and, liberated from the superficial and vain material life, release itself to the exalted experience, sensation and rational analysis of that experience. Barrès' later cult of nationalism is to 


\section{L'ESPRIT CRÉATEUR}

be read as passing from the interior landscape of the moi to another interior, yet collective landscape, the race. His second major work, Roman de l'énergie nationale (1897-1902), not only exploits the personal "culte du moi," but inscribes it within the deeper, primary "culte de la terre." In the first novel of the trilogy, Les Déracinés (1897), the heroes become the new martyrs uprooted from their native soil and tossed into the unauthentic and destabilizing world of modernity, their youthful energy slowly sapped by an urban life growing more and more abstracted. If individual will proves ineffective against the encroaching collectivism of modern society, then a collective will is called for. But a collective will implicates the People, the masses, and flirts dangerously then with anarchy and revolution.

The "culte du moi," the exaltation of the will, of inner experience either intuitive or subliminal, even the derisory discovery of the force of contingency, of chance-these gestures seem to reiterate the extraordinary enthusiasm for energy of the eighteenth century's fin-de-siècle, its vitalism, and the regenerative, primary force which $\mathbf{M}$. Delon has so masterfully outlined in his work on the subject. ${ }^{12}$ The politically engaged France of the nineteenth century's fin-de-siècle seems transfixed by its ties to the past, to the vitalistic thrust of a regenerative violence indigenous to revolutionary action. The politically disengaged also betray a desire for a regenerative force of sorts, however hidden under the guise of artifice. Beneath the decadent's enervated rapture and ennui lies what C. Rosset has called "une nostalgie naturaliste": his desire to escape, "une nostalgie d'une nature absente." 13

Forced to live out history, revolutionary France lived in history. And though her ideals were indeed future-oriented, the new City nevertheless found its expression in an ever-open present: in the myriad fêtes révolutionnaires, in the libertine celebration of the sexual utopias of a Sade or Rétif; in the aborted monuments to rationalized reality of Ledoux or Boulle; in a revolutionary theater that reenacted ad nauseam the epiphanic pulsebeat of originary violence. It is revolutionary France, after all, that achieves the "end of history" writing "out" its end. As F. P. Bowman reminds us, there was, strictly speaking, no eighteenth century fin-de-siècle, no 1799 nor 1800, since France had invented a new time, a new space: "Eighteen hundred was not officially the beginning of a new 
century for the French, who were still under the Revolutionary calendar, in the year VIII or IX; nor was 18 Brumaire (10 October 1799), when young Bonaparte seized power, seen by many at the same time as a new beginning; rather it was just one more of those coups d'état. . . ."14

Fin-de-siècle France of the period 1789-1799 not only recuperated classical forms and ideals but invented a purely phantasmal and archaic energy retrieved from the barbarism of its mythical past upon which it drew and with which it infused its utopian projects. Thus Germaine de Staell lamented the degeneration into barbaric incantations of the classical oratory of revolutionary discourse:

Nous sommes arrivés à une période qui ressemble, sous quelques rapports à l'état des esprits au moment de (...) l'envahison des peuples du Nord [...] sans la pensée, sans les sentiments, sans la vérité, comme une espèce de litanie, comme si l'on exorcisait avec des phrases convenues l'éloquence, la raison [...]. ${ }^{15}$

And it was precisely one of these orators who suggested that the Revolution retrieve the violent force of a barbaric age, as Saint-Just remarked:

Depuis plusieurs siècles, la monarchie nageait dans le sang et ne se dissolvait pas. Mais il est une époque dans l'ordre politique où [...] tout se déprave et dégénère [...]. Alors, si quelque peuple barbare se présente, tout cède à sa fureur, et l'Etat est régénéré par la conquête, s'il n'est point attaqué par les étrangers, sa corruption le dévore et le reproduit. (46)

Modern "barbarians" and primitive "esthetes" abound in revolutionary France, certainly if one is to read the literature of emigration, and well before Hydropathes, Zutistes, Jemenfoutistes, anarchists of the modern fin-de-siècle period. The word "vandalism," invented by the Revolution's Abbé Grégoire to describe what he saw as the systematic attack against state property, was originally a term to designate the actions of counter-revolutionaries. It soon took on the ambiguous coloration of legitimate, revolutionary practice. As uncontrolled destruction of property, it could be used as a terrorist tool against the enemy; as the systematic dismantling of ancien régime art, it contributed to the project of regenerating the nation. In 1794 a revolutionary, La Harpe, proposed the destruction of all royal emblems on the books of the new Bibliothèque Nationale (50). A year earlier, David contributed to the "vandalist"' spirit by proposing to erect a colossal monument to the French People out of the "dismembered fragments" from the systematic destruction of royal statues. ${ }^{16}$ In a recuperative gesture to Greek Antiquity, several 


\section{L'ESPRIT CRÉATEUR}

of David's pupils formed a highly original sect known as the "Barbus" or "primitifs" who took the neoclassic ethic of extreme purity and simplicity quite literally. They dressed in phrygian robes and tunics, grew their hair and beards, lived in sparsely furnished surroundings in their studios, where they dealt solely with the works of the Ancients and judged any participation with the real as suspicious (136).

Though modern fin-de-siècle iconoclasm seems at times but a shadow of revolutionary France's very real practice of a regenerative violence, can one say the same regarding philosophy? Nothing would appear further from our fin-de-siècle philosophy than the positivistic spirit of Enlightenment rationalism, its obsession with "système," or its quasireligious cult of progress. But then, this is to forget that revolutionary speculative theory cannot be reduced to that of the 1750 generation, but, rather, should be judged in light of what the thinkers of the 1789 generation were writing - those victims of yet another collective amnesia, the Ideologues. Posterity would have us equate revolutionary French thinkers only with those students of Voltaire, Diderot, D'Alembert, and Rousseau, when our attention should turn to Cabanis, Destutt de Tracy, Lacretelle, Bichat, Volney, and others. The Ideologues stand rightly accused of embracing Enlightenment empiricism and, along with it, its systematic and often restrictive breakdown of knowledge into finer and finer specializations. Furthermore, the roots of nineteenth-century positivism can easily be traced to any number of Ideological thinkers. ${ }^{17}$ Yet, the Ideologues' project also represents a major shift in the object of what speculative thought is and does: henceforth, speculation turns from facts to thoughts and from results to processes. It indeed shared the Encyclopedists' endeavor to totalize knowledge but it rejected their purely mechanistic and quantitative approach to knowledge to make way for a pluralistic and organic one. ${ }^{18}$ Attempting to uncover the common roots of the separate domains of human knowledge, they affirmed the principle of interdisciplinary thought that alone could claim any legitimate mastery of knowledge. Suspicious by then of the romanticized portrait of the solitary thinker - the lonely philosopher in his cabinet, the "génie"the Ideologues dismissed the privacy and primacy of the knowing Subject or his acquisitive desires to claim knowledge as his property. Tracy's monumental Eléments d'Idéologie becomes tiresomely redundant in its constant acknowledgement of debt to its Enlightenment fathers and modern collaborators: philosophy is conceived as a collective project that seeks "the elucidation of mental space" (Gusdorf, 332 and 364). 
Evacuated also are the notions of transcendence, innate ideas, or original truths (326). To have embraced Lockean empiricism and the sensationism of Condillac meant also to refuse categorically any notion of philosophy's ontological objectives. Or rather, ontology became epistemology, a reflection on the science of reflection. For the Ideologues, even the word metaphysics is considered a suspicious holdover from superstition and "traditional" philosophy, moving Tracy to replace it altogether with a new term: "Je préférais donc de beaucoup que l'on adoptât le nom d'idéologie, ou sciences des idées (...) (360). To the analysis of problems, origins, and truth, the Ideologues respond with an analysis of "l'entendement," and metaphysics is reduced to a mere appendage of physiology: "La vraie métaphysique ou la théorie de la logique n'est donc autre chose que la science de la formation de nos idées, de leur expression, de leur combinaison ou de leur déduction, en un mot ne consiste que dans l'étude de nos moyens de connaître" (366). The science of ideas requires a science of language: its grammar, logic, syntax, a critique of signs. This explains why Condillac played a central role as founder of the school of the Ideologues, who was the first to affirm that "languages were analytical methods that guided our intelligence in its calculations" (366). For the Ideologues, the "ends" of philosophy meant the "end of metaphysics" in the sense that all philosophy was to do or be is the analysis, decomposition, comparison, identification of relationships, processes of thought, ideas and perceptions. A science of ideas, the school of the Ideologues ambitioned "a theory of theory" that in the end would translate the analytical structure of consciousness and, by extension, the structure of the universe itself.

It is precisely this desire to unfold the underlying structure of the universe which received posterity's harshest criticism against the fin-desiecle speculative experiment of the Ideologues. Furthermore, these finde-siècle thinkers enthusiastically embraced the marriage between theory and politics. What other school of philosophy could link its inception to the same moment of the birth of the new nation and write itself into existence as the pedagogical and philosophical application of French revolutionary ideals? These speculators refused to consider themselves as philosophers but preferred to be seen as scientists, geographers, literary historians, doctors, biologists, chemists, theoreticians. The regeneration of the nation lay at the center of their science, drove the energy of their theories (381). And, like most revolutionary projects, the Idéologues fell victim to their own "élan" that was always ready to self-destruct in 


\section{L'EsPrit Créateur}

the meanderings of endless analysis. The Ideologues' most ambitious organizations - the Institut, the Ecoles centrales and the Ecole Normale -enjoyed but brief notoriety and political importance. The Ecole Normale of L'An III had to close in less than a year for reasons of incoherence, of overly ambitious programs that proved impossible to teach; or at least its public was not yet ready for a program whose foremost goal was the theoretical teaching of method, the method being analysis, or, as one member explained,

L'Ecole normale ne doit avoir pour objet que d'enseigner toutes les sciences. Cette méthode est certainement l'analyse, et non la synthèse [...]. L'Ecole normale devrait donc avoir pour but unique d'enseigner comment l'analyse s'applique avec succès aux différentes parties des connaissances humaines. Mais avant de montrer comment l'analyse opère, il faut faire connaître ce grand instrument de la science avant d'apprendre à le manier. Or l'analyse de l'entendement peut seule donner cette connaissance, parce que c'est sur l'entendement qu'il s'agit d'opérer par l'analyse [...]. (382)

It is the break with the Enlightenment's "synthetic" project and the Ideologues' fascination with "analysis" that marks their participation with modernity. A fitting illustration of the unsettling openness of their analytical method might be Tracy's following commentary on Montesquieu's notion of law:

Les lois ne sont pas, comme le dit Montesquieu, Les rapports nécessaires qui dérivent de la nature des choses. Une loi n'est pas un rapport, et un rapport n'est pas une loi [...] nous entendons par une loi, une règle prescrite à nos actions par une autorité que nous regardons comme ayant le droit de faire cette loi. Cette dernière condition est nécessaire; car, lorsqu'elle manque, la règle prescrite n'est plus qu'un ordre arbitraire, un acte de violence et d'oppression.

Cette idée de la loi renferme celle d'une peine attachée à son infraction, d'un tribunal qui applique cette peine, d'une force physique qui la fait subir. Sans tout cela, la loi est incomplète ou illusoire. ${ }^{19}$

In a lengthy and convoluted development, Tracy goes on to describe the notion of natural law as necessity which seems to occur as if an invincible authority had ordered it-with no apparent "right to do so," however. Further, positive law, that is, conventional law, must appear to derive from natural law-again, the "right" behind the authority being as real or as illusory as one makes of it from this text. Tracy's methodical dismantling of law, while obvious in its systematic dépouillement of the more general ideas surrounding the notion, arrives at a "fundamental" core or element only to invert the very notion of law, precariously plac- 
ing it in an analogous relation to its other: arbitrary authority or violence. Has analysis led us to elucidation or illusion? Or elucidation as illusion? It is perhaps not surprising that Tracy's final sections to the Eléments d'Idéologie, entitled Traité de la Volonté, suggest that it is an exploration and study of the order of desire that will ultimately lead science to the foundation of our reason, our becoming, our knowledge and our finality. The Ideologues' obsession with analysis and method, their desire to map the entirety of human knowledge, reveals an obsession with origins or with beginnings in the sense that the impossibility of the project ensures the endless repetition of beginning over again, the uncovering, dismantling, and analysis of yet another object or phenomenon of scrutiny-a sort of regenerative principle of knowledge whereby the philosopher is always renewing his own creation.

P. Muray has expressed the idea that we have never left the nineteenth century. ${ }^{20}$ However, the question might now be whether it is, rather, a question of having never left the eighteenth century. Another sign of the times: if we are to believe certain French and American bestsellers (Allan Bloom), "culture" is on the decline, always and already threatened with being taken over again by the "barbarians," the same who were so dear to Barrès. Some of these works, such as Alain Finkielkraut's La Défaite de la pensée, are both theoretical and symptomatic of the phenomenon they set out to explain. ${ }^{21}$ I see two opposing and conflicting paradigms that have coexisted since the eighteenth century. The first one, forming a long chain from Herder and de Bonald to Barrès and the philosophy of decolonization and multiculturalism, makes itself the champion of national identity and the relativism of all cultural value. I take for granted that this paradigm entertains ties, sometime paradoxical, with the unconscious, race or heredity. The second paradigm, that of the Enlightenment, postulates the existence of reason and universal values which Julien Benda and, after him, Alain Finkielkraut espouse. And with the demise of communism, the latter even announces that the catastrophic victory of Joseph de Maistre over Karl Marx is imminent (92). In conclusion then, that which the Unified Team, mentioned earlier, signified was nothing less than the eternal return of the eighteenth century and the very unexpected posthumous victory of a de 


\title{
L'ESPRIT CRÉATEUR
}

\author{
Maistre and Vicomte de Bonald over Francis Fukuyama and the New \\ World Order.
}

University of Kansas

\section{Notes}

1. Details of the event taken from “Aux Barricades! 'La Marseillaise' Is Besieged," The New York Times, March 5, 1992.

2. A "pastoral" version of the Marseillaise had already been proposed during Rouget de Lisle's time by the revolutionary lyricist/musician, François de Neufchâteau who offered the following lyrics: "Allons, enfants du labourage,/Poussez le soc avec vigueur.../Aux armes laboureur! prenez votre aiguillon,/Marchez, marchez (bis); qu'en boeuf docile ouvre un large sillon."' (Quoted from B. Didier, Ecrire la Révolution 1789-1799 [Paris: PUF, 1989], 125.)

3. See H. Eichberg's article, "Forward Race and the Laughter of Pygmies: On Olympic Sport," Fin de Siecle and Its Legacy, ed. M. Teich and R. Porter (Cambridge, England: Cambridge Univ. Press, 1990), 115-31.

4. J. Habermas, "Modernity's Consciousness of Time and Its Need for Self-Reassurance," The Philosophical Discourse of Modernity, trans. F. G. Lawrence (Cambridge, Mass.: The MIT Press, 1990), 5-11.

5. See Thomas Crow's admirable study, "Revolutionary Activism and the Cult of Male Beauty in the Studio of David," Fictions of the French Revolution, ed. B. Fort (Evanston: Northwestern Univ. Press, 1991), 55-84.

6. I am thinking of Gustave Moreau's OEdipe, for example, or similarly, the eroticization of female figures such as Albert Besnard's Marianne of the ceiling painting of the Petit Palais (see D. Silverman, "The 'New Woman,' Feminism, and the Decorative Arts in Fin-de-Siècle France,"' Eroticism and the Body Politic, ed. L. Hunt (Baltimore: The Johns Hopkins Univ. Press, 1991), 143-46). See also John Neubauer's recent book, The Fin-de-Siecle Culture of Adolescence (New Haven: Yale Univ. Press, 1992).

7. Quotation from J. Starobinski, 1789. Les Embiemes de la Raison (Paris: Flammarion, 1979), 78-79.

8. Ibid., 81 .

9. Eugen Weber, France, Fin de Siecle (Cambridge, Mass. and London: The Belknap Press of Harvard Univ. Press, 1986), 1.

10. C. E. Schorske, Fin-de-Siecle Vienna. Politics and Culture (New York: Vintage Books, Random House, 1981), xxvi.

11. Fritz R. Stern, The Politics of Cultural Despair. A Study in the Rise of the Germanic Ideology (Berkeley and Los Angeles: Univ. of California Press, 1961), 267-98.

12. 'Idée-force, [l'energie] participe à la constitution d'une linguistique de l'effet, d'une esthetique de la création, à la définition de la physique et de la chimie comme sciences des relations, à une représentation du monde et de l'individu comme devenir. Mais elle trouve sa limite dans le goüt des paroxysmes, dans le terrorisme politique et dans l'immoralisme sadien. Principe du mouvement, elle assure également une mobilité des principes: c'est une idee-carrefour qui se caractérise par la rencontre de domaines traditionnellement distincts, d'attitudes philosophiques jugees antagonistes." Michel Delon, L'Idée d'énergie au tournant des Lumieres (1770-1820) (Paris: PUF, 1988), 517.

13. See Clément Rosset's discussion, “Esthétique de l'artifice,” regarding French writers and artists of the second half of the nineteenth century, in his L'Anti-Nature (Paris: PUF, 1973), 99-123.

'14. Quoted from the New History of French Literature, ed. Denis Hollier (Cambridge, Mass. and London: Harvard Univ. Press, 1989), 596.

15. Quotation from Pierre Michel, Un Mythe romantique. Les Barbares, 1789-1848 (Lyon: Presses Universitaires de Lyon, 1981), 46. B. Didier adds "l'Antiquité est une résurgence du mythe de l'Age d'Or, une promesse de régéneration; se plonger dans la tradition antique, c'est retrouver une vigueur première, c'est retrouver une sagesse, un langage perdus (...) imiter l'Antiquité, ce n'est pas revenir en arrière, c'est renouer 


\section{FOURNY}

avec les forces vives de la poésie et de la nature, pouvoir rebâtir un monde, un art veritablement forts" (op. cit., 97).

16. See "Revolutionary Vandalism," in Lorenz Eitner, Neoclassicism and Romanticism. 1750-1850 (Englewood Cliffs, NJ: Prentice-Hall, Inc., 1970), 140-42.

17. Georges Gusdorf, La Conscience révolutionnaire. Les Idéologues (Paris: Payot, 1978), 326 and 355.

18. It should be mentioned in passing that Schopenhauer's theory of will issued from the "vitalist"' theories of Cabanis and Bichat. See C. Rosset, Schopenhauer, philosophe de l'absurde (Paris: PUF, 1967), 41.

19. Destutt de Tracy, Commentaire sur 'L'Esprit des Lois" de Montesquieu (Paris: Delaunay, Libraire, 1819), 1-6.

20. Philippe Muray, Le Dix-neuvième siècle à travers les âges (Paris: Denoël, 1984).

21. Alain Finkielkraut, La Défaite de la pensée (Paris: Gallimard, 1987). 